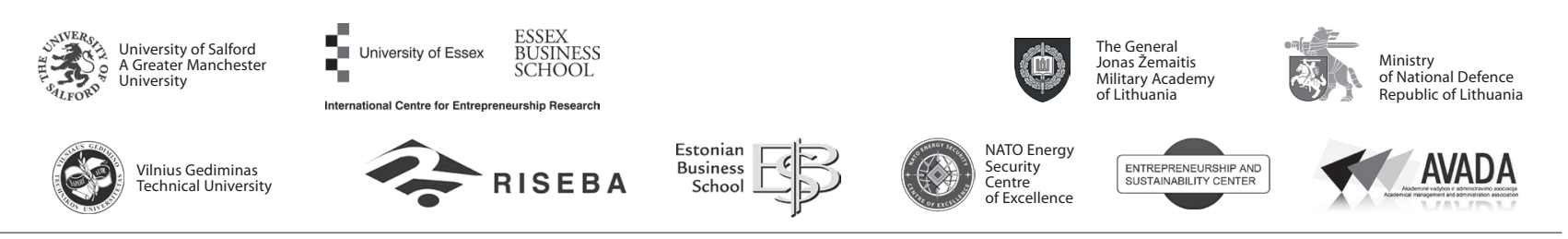

\author{
JOURNAL OF SECURITY AND SUSTAINABILITY ISSUES \\ ISSN 2029-7017 print/ISSN 2029-7025 online \\ 2017 September Volume 7 Number 1 \\ http://dx.doi.org/10.9770/jssi.2017.6.1(14)
}

\title{
INFORMATION SYSTEMS FOR SUSTAINABLE PERFORMANCE OF ORGANIZATIONS
}

\author{
Rastislav Rajnoha ${ }^{1}$, Antonín Korauš² Ján Dobrovič $^{3}$ \\ ${ }_{1,2}$ Paneuropean University in Bratislava, Faculty of Economics and Business \\ Tematinská 10, 85105 Bratislava, Slovak Republic \\ ${ }^{3}$ University of Prešov in Prešov, Faculty of Management \\ Konštantínova 16, 08001 Prešov, Slovak Republic
}

E-mails: ${ }^{1}$ rastislav.rajnoha@paneurouni.com; ${ }^{2}$ antonin.koraus@paneurouni.com; ${ }^{3}$ jan.dobrovic@unipo.sk

Received 16 August 2016; accepted 20 March 2017

\begin{abstract}
Since the mid-1990s, enterprise resource plannig (ERP) information systems have been installed in thousands of companies worldwide. A growing number of studies and research papers show that information systems have a significant role in the sustainable economic development assuring economic competitiveness. Modern enterprise performance management shares a strong strategic and sustainable orientation of management focused on further strategic growth and business development with parallel use of information and all highly sophisticated knowledge resulting from modern enterprise information technology. The paper focuses on research findings related to information processes and their impact on overall entrepreneurship performance. The most important results show that the companies from the selected industrial segments in Slovakia have a strong focus on the application of innovation procedures and specific business information systems. The results bring the findings that business intelligence (BI) is based on information and knowledge with a high added value has a positive long-term and sustainable effect on the overall entrepreneurship performance. By application of selected management tools such as ERP, BI information systems and others, it can be achieved a higher entrepreneurship performance of industry companies in Slovakia and EU. We believe that our study presented in this paper contributes to explore a new dimension to the existing view on business information systems in industrial companies. More detailed research results are presented in this paper.
\end{abstract}

Keywords: sustainability, sustainable performance management, information system, innovation

Reference to this paper should be made as follows: Rajnoha, R.; Korauš, A.; Dobrovič, J. 2017. Information systems for sustainable performance of organizations, Journal of Security and Sustainability Issues 7(1): 167-179.

http://dx.doi.org/10.9770/jssi.2017.6.1(14)

JEL: M21, M15

\section{Introduction}

Today, innovation is increasingly complex, fast, interactive, and requires the access to external and internal knowledge in order to develop new or significantly improved good and service (Prause, 2015). Innovation is known to be one of the keys to an enterprise success. Knowledge creation and dissemination, as well as innovation, are keys to promotion of competitiveness (Aleksejeva, 2016; Tvaronavičienė et al. 2016; Čirjevskis, 2016). 
Higher-quality, lower-cost information is a key to unlocking more sources of finance for SMEs (Belás et al., 2016). Many companies continue to increase their investment in implementing various types of information systems, such as Enterprise Resource Planning (ERP), Customer Relationship Management (CRM) and Business Intelligence (BI). These solutions for decision-making support are based on the Integrated MIS, including specialized Business intelligence modules which are aimed to provide support in the decision-making process of the management (Tutunea \& Rus, 2012). Most of the above progressive methods of entrepreneurship performance management shares a strategic and sustainable orientation focused on further strategic development with parallel use of highly sophisticated knowledge resulting from information technologies such as BI, or Big Data Analytics.

The aim of this paper is to identify the relationship between selected management tools such as information systems and others to overall business performance in industry companies in Slovakia. Based on the research results, we can conclude that the subjected area of research in terms of businesses Slovak industry is extremely important for enhancing companies' performance (Rajnoha, Novák \& Merková, 2016). By application of selected management tools such as ERP, CRM and Business Intelligence IS and others, it can be achieved a higher performance of enterprises. More detailed research results are presented in the following sections of this paper.

\section{Literature review}

The current time puts high demands on managers, as well as other employees, forcing them to think about how best to optimize business processes. Innovation and entrepreneurship are becoming key concepts for economic sustainable development in today's complex and dynamic business world (Rosha \& Lace, 2015). Today, the sustainable and secure development has become an actual and urgent matter in many countries around the world (Korauš et al., 2016; Kriviņšs, 2015; Belás et al., 2016). Innovation is a perfect space, because its outputs affect the sustainability of the company and from the perspective of the customer as well as the owners of the company (Chromjaková \& Rajnoha, 2009; Čirjevskis, 2016; Illmeyer et al., 2017). Innovation by Chromjaková and Rajnoha (2009) may be a strategic, it may be focused on new product development, and innovative approach to problem solving, innovation can be identified as the process of generating and implementing ideas. Innovation is understood as the result of interaction between various economic and social processes (Manley, 2003). Studies published in the last decade showed that innovation is the engine of the growth, being an important element of the development achievements (Szabo, Soltés, \& Herman, 2013; Chernov, Dorokhova \& Dorokhov, 2016). Innovation activities play an important role in economic growth and can be considered as the engine of sustainable development of economies (Juřičková \& Novák, 2015; Belás \& Gabčová, 2016; Rosha \& Lace, 2015; Čirjevskis, 2016; Tvaronavičiené, 2017; Tetsman et al., 2017; Oganisjana et al., 2017).

These activities are influenced by many factors that have mostly synergy effects and work on process and final product level. The premise is that more factors enter the innovation process and are necessary for successful innovation performance. It is necessary to analyse more factors in detail and complexly and include other factors entering innovation such as investment in research and development, human capital represented by number of researchers, the role of information technologies in the twenty first century, etc. (Juřičková \& Novák, 2015, Ignatavičius et al., 2015; Tvaronavičienè, M.; Černevičiūtè, 2015; Akhter, 2017).

Since the mid-1990s, ERP have been installed in thousands of companies worldwide. ERP systems are enterprise-wide on-line interactive systems that support cross-functional processes using a common database. ERP systems were designed to provide, at least in theory, seamless integration of processes across functional areas with improved workflow, standardization of various business practices, and access to real-time up-to-date data (Mabert, Ashok, \& Venkataramanan, 2003). Enterprise resource planning information systems (ERP) are highly complex business information systems. The implementation of these systems requires a high cost, corporate time and resources (Umble, Haft, \& Umble, 2003). Organizations continue to increase their investment in implementing various types of information systems, such as ERP, SCM, BI or CRM, because these investments will lead to higher employees' productivity (Hou, 2012). The commercially available ERP information system promise seamless integration of all information flows in the company (Tuček, Tučková, \& Zámečník, 2009). 
High dynamic environment significantly affects the overall efficiency and so also the competitiveness of companies. Competitive advantage comes from the ability of an organization to compete in new technologies and markets where flexibility, autonomy, and experimentation are needed (O'Reilly \& Tushman, 2013; Čirjevskis, 2016). One of the conditions to maintain the sustainable competitiveness and performance of the company is the ability to work with information not only about past and present but especially about the future. Management of "todays" company is constantly forced to look for additional useful information especially about the future development. This task is currently being performed by ERP systems of II. development type based on BI - Business Intelligence information systems - Fig. 1 (Basl \& Blažíček, 2008).

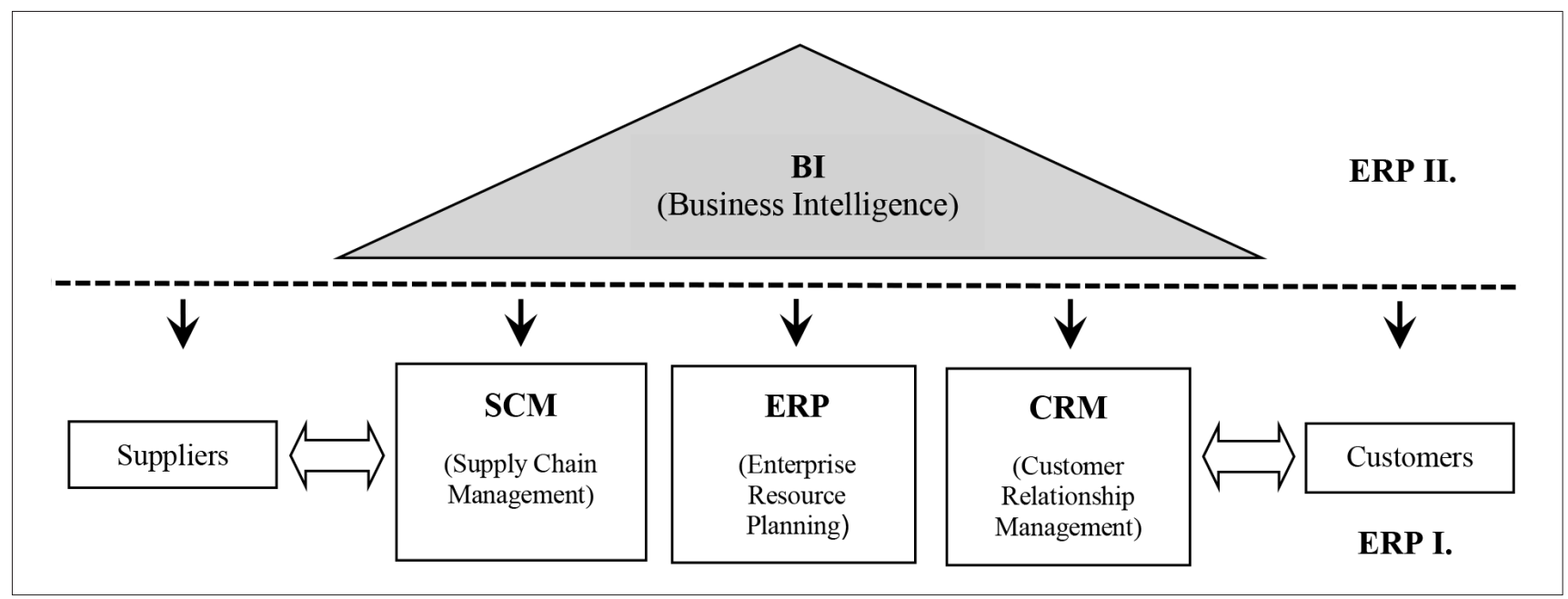

Figure 1. Advanced enterprise information systems ERP II - Business Intelligence.

Source: Basl \& Blažíček, 2008

Typical BI application scopes include: ERP, CRM, HRM (Human Resource Management), SCM and E-business (Li, Shue, \& Lee, 2008). These systems convert and store the data in their databases; therefore, they can be used as a pool of data to support decisions and explore applicable knowledge. BI is often used to refer to relevant information of internal and external business environment and also refer to an organized and systematic process acquiring, analyzing and disseminating information for decision making (Lönnqvist \& Pirttimäki, 2006). Building of comprehensive information, and information about the historical implications, events, interesting details and attractiveness directly in visited sites and destinations should be part of strategic communication (Štefko, Királová \& Mudrík, 2015). The significance of online marketing is currently increasing, as we can observe changes in the ways people communicate and also in the ways they spend their free time (Štefko, Fedorko \& Bačík, 2015). ERP implementation in middle and large companies always takes several years and the whole process requires human, financial, material and other resources. Therefore, it is advisable to use project-based management approach when implementing ERP systems in companies (Rajnoha et al., 2014). An ERP system integrates core corporate activities and diverse functions, such as accounting, management of customer information, finances, human resources, supply chain, etc., by incorporating best practices to facilitate rapid decision-making, cost reduction, and greater managerial control (Wu \& Wang, 2007). A lot of work has been already done to identify and classify the costs and benefits of ERP, including both the implementation and post-implementation stages (Hitt et al., 2002; Rajnoha et al., 2014). Also, the aspect of the success or failure of ERP has been widely analyzed (Wu \& Wang, 2007; Rajnoha et al., 2014), resulting in the development of approaches that reduce the risk failure of an ERP implementation (Ram \& Corkindale, 2014; Rajnoha et al., 2014). However, studies of the financial impact of ERP adoption suggest that benefits are uneven. On the positive side, event history analyses have found positive abnormal stock returns for firms using ERP (Stratman, 2007). Hitt, Wu, and Zhou (2002) also found evidence of improved financial performance immediately after ERP implementation. Survey data from North American manufacturing firms that have implemented ERP systems demonstrate that ERP adopters seeking operational performance improvements are likely to realize these benefits (Stratman, 2007). Also other international research studies have found clear improvements in operational metrics as a result of ERP implementation (McAfee, 2002; Cotteleer, 2006). 
Implementing a new information system is not always to the benefit of a company. The success of system implementation is dependent on many factors. When a business implements ERP in its drive to become more efficiently interconnected, risks arise from the new technology, which is loaded with uncertainties that evolve over time and cannot be fully known when making decisions (Wu, Ong, \& Hsu, 2008). A major problem with ERP implementation process is that very few threat and risk of implementation failures are recorded in the literature, perhaps because few companies wish to publicize their implementation failures (Hakim \& Hakim, 2010). The primary task of an integrated system is to maintain the data flow of an organization and to reduce data redundancy. In recent years, the advancement of information technology in business management processes has placed ERP systems as one of the most widely implemented business software platforms in various enterprises. ERP systems have the potential to integrate seamlessly organizational processes using common shared information and data flows (Relich, 2013).

The current research in the computer systems and Information technology predetermine Cloud Computing as the more effective solution in terms of effective application of BI to Enterprise (Chen, Chiang, \& Storey, 2012; Rajnoha et al., 2016). BI applications allowed managers to acquire useful knowledge from the data by means of a variety of technologies, such as data warehousing, data mining, business performance management, OLAP, periodical business reports, Big Data Analytics.

\section{Analysis about usage of ERP in EU countries}

In recent years enterprises in the EU countries were invested a lot of financial resources into the implementation of ERP information systems. The Table 1 presents the usage of ERP IS by large enterprises (without financial enterprises) in selected EU countries in years $2012-2015$.

The statistical results (Table 1) show that the highest rate of usage of ERP in the year 2015 is related to the large enterprises (more than 250 employees) from Germany (93\%), Austria (93\%), Denmark (92\%), Portugal (92\%) and Slovenia (92\%). The lowest rate of ERP implementation was achieved in EÚ countries such as Greece (59\%), Romania (60\%), Bulgaria (61\%), United Kingdom (63\%), Estonia (63\%), Latvia (63\%) and Ireland (64\%). The highest rate of usage of ERP in V4 countries achieves Poland (83\%), followed by Czech Republic (82\%), Slovakia (71\%) and Hungary (69\%). The average rate of ERP use in European Union (28 countries) was 80\% (2015).

Table 1. EU large enterprises that have implemented ERP information system (in \%)

\begin{tabular}{|c|c|c|c|c|}
\hline $\begin{array}{ll}\text { Country } & \text { Year } \\
\end{array}$ & 2012 & 2013 & 2014 & 2015 \\
\hline European Union (28 countries) & 68 & 73 & 76 & 80 \\
\hline Belgium & 76 & 79 & 88 & 89 \\
\hline Bulgaria & 46 & 47 & 57 & 61 \\
\hline Czech Republic & 79 & 76 & 81 & 82 \\
\hline Denmark & 82 & 84 & 86 & 92 \\
\hline Germany & 73 & 82 & 84 & 93 \\
\hline Estonia & 53 & 51 & 56 & 63 \\
\hline Ireland & 61 & 68 & 65 & 64 \\
\hline Greece & not available & 72 & 82 & 59 \\
\hline Spain & 63 & 75 & 75 & 79 \\
\hline France & 78 & 79 & 78 & 84 \\
\hline Croatia & 56 & 65 & not available & 79 \\
\hline Italy & 68 & 73 & 79 & 79 \\
\hline Cyprus & 73 & 65 & 78 & 84 \\
\hline Latvia & 39 & 39 & 44 & 63 \\
\hline Lithuania & 58 & 76 & 88 & 86 \\
\hline Luxembourg & 65 & 79 & 76 & 79 \\
\hline Hungary & 53 & 62 & 68 & 69 \\
\hline Malta & 55 & 58 & 72 & 69 \\
\hline Netherlands & 72 & 75 & 81 & 80 \\
\hline
\end{tabular}




\begin{tabular}{|l|l|l|l|l|}
\hline Austria & 84 & 89 & 90 & 93 \\
\hline Poland & 69 & 77 & 82 & 83 \\
\hline Portugal & 84 & 87 & 91 & 92 \\
\hline Romania & 49 & 51 & 58 & 60 \\
\hline Slovenia & 87 & 92 & 92 & 92 \\
\hline Slovakia & 62 & 64 & 69 & 71 \\
\hline Finland & 83 & 85 & 86 & 86 \\
\hline Sweden & 83 & 88 & 85 & not available \\
\hline United Kingdom & 48 & 51 & 56 & 63 \\
\hline Norway & 65 & 72 & 74 & 77 \\
\hline
\end{tabular}

Source: Eurostat, 2016

The statistical results about use of ERP in the year 2015 related to the medium enterprises (50-249 employees) are reflected in Table 2. The average rate of ERP use in European Union (28 countries) was only 60\% (2015). The highest and above average rate of usage of ERP in EU countries achieves Germany (80\%), followed by Cyprus (75\%), Portugal (75\%), Belgium (74\%), Denmark (74\%), and Austria (70\%). The lowest rate of ERP implementation was achieved in EÚ countries such as Latvia (28\%), Romania (33\%), United Kingdom (39\%), Estonia (40\%), Bulgaria (41\%), Malta (41\%) and Ireland (42\%). The highest rate of usage of ERP in V4 countries achieves Czech Republic (58\%), followed by Slovakia (48\%), Poland (47\%) and Hungary (36\%).

Table 2. EU medium enterprises that have implemented ERP information system (in \%)

\begin{tabular}{|c|c|c|c|c|}
\hline $\begin{array}{|ll|}\text { Country } & \text { Year } \\
\end{array}$ & 2012 & 2013 & 2014 & 2015 \\
\hline European Union (28 countries) & 44 & 49 & 54 & 60 \\
\hline Belgium & 61 & 64 & 72 & 74 \\
\hline Bulgaria & 30 & 30 & 39 & 41 \\
\hline Czech Republic & 51 & 49 & 53 & 58 \\
\hline Denmark & 61 & 62 & 69 & 74 \\
\hline Germany & 48 & 60 & 62 & 80 \\
\hline Estonia & 19 & 28 & 33 & 40 \\
\hline Ireland & 34 & 38 & 39 & 42 \\
\hline Greece & not available & 66 & 70 & 67 \\
\hline Spain & 46 & 57 & 61 & 60 \\
\hline France & 60 & 60 & 61 & 67 \\
\hline Croatia & 31 & 41 & $:$ & 48 \\
\hline Italy & 48 & 53 & 62 & 62 \\
\hline Cyprus & 45 & 53 & 63 & 75 \\
\hline Latvia & 18 & 18 & 19 & 28 \\
\hline Lithuania & 33 & 52 & 59 & 59 \\
\hline Luxembourg & 35 & 51 & 58 & 58 \\
\hline Hungary & 23 & 32 & 35 & 36 \\
\hline Malta & 34 & 36 & 42 & 41 \\
\hline Netherlands & 53 & 60 & 67 & 69 \\
\hline Austria & 53 & 60 & 70 & 70 \\
\hline Poland & 28 & 38 & 49 & 47 \\
\hline Portugal & 57 & 62 & 66 & 75 \\
\hline Romania & 25 & 25 & 32 & 33 \\
\hline Slovenia & 53 & 57 & 56 & 57 \\
\hline Slovakia & 34 & 44 & 46 & 48 \\
\hline Finland & 63 & 69 & 68 & 64 \\
\hline Sweden & 61 & 64 & 68 & not available \\
\hline United Kingdom & 24 & 25 & 30 & 39 \\
\hline Norway & 42 & 49 & 57 & 54 \\
\hline
\end{tabular}




\section{Research sample and methodology}

The useful data and information we have obtained with help of an extensive questionnaire survey. We have asked 1.457 chosen businesses, representing various industries in Slovakia. The particular data about the primary database of 1.457 enterprises were received from information of various industrial associations. The questionnaires were correctly responded by 164 enterprises. We consider the size of the research sample sufficiently representative and this was $11.26 \%$ share of the total number of companies surveyed. The Figure 2 shows the survey sample in terms of size of company. The large and medium enterprises formed $40.3 \%$ share. Micro and small enterprises accounted for $59.7 \%$ share of the research sample.

\section{Survey sample in terms of size of company}

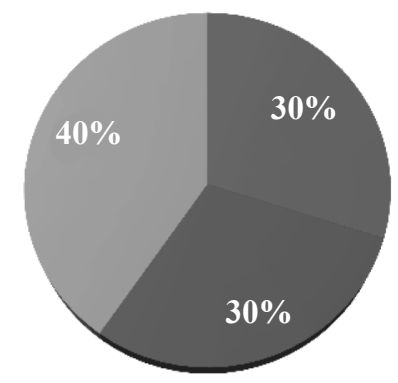

- Micro sized enterprises (to 10 employees)

- Small enterprises (11-50 employees)

- Medium and large enterprises (over 51 employees)

Figure 2. Survey sample in terms of size of company

Source: own

The greatest extent was represented by businesses of engineering, wood and automotive industries. In order to identify and analyze the parameters for business performance management, a key issue was the size of Return on equity (ROE). Based on this, we have incorporated enterprises in various performance categories with six scaled intervals. The differentiation of enterprises into the performance groups is shown in Figure 3.

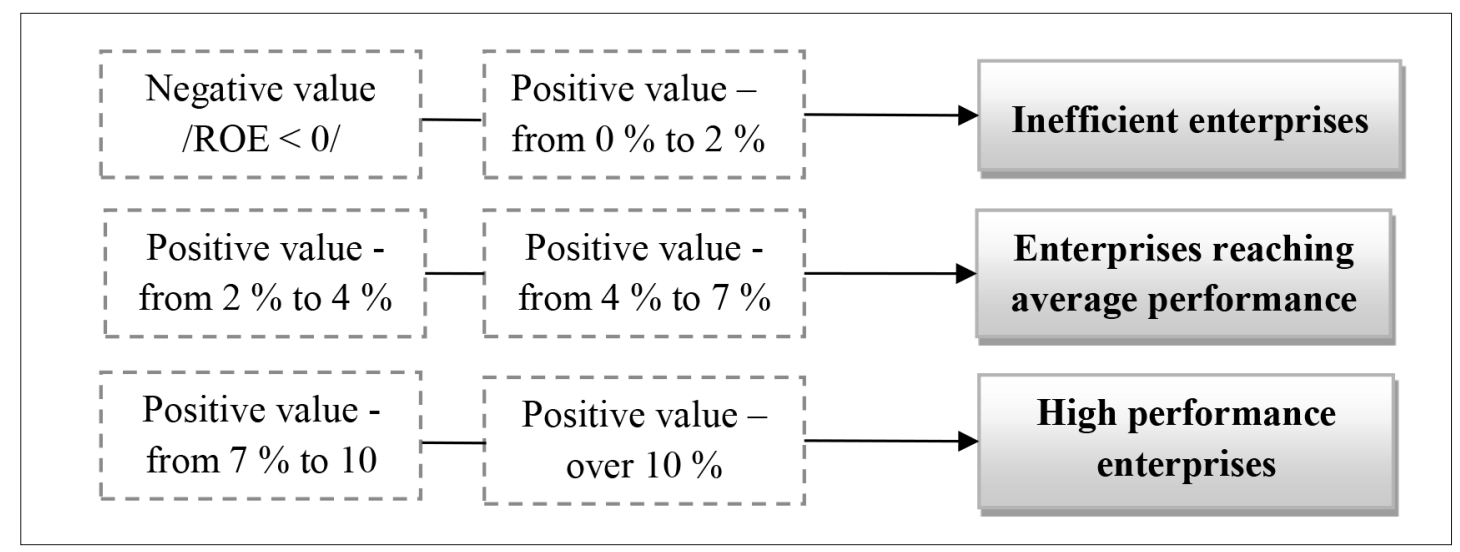

Figure 3. The enterprise categorization into the performance groups

\section{Source: own}

The results obtained by questionnaire survey were processed by statistical methods. Selected variables were processed by descriptive statistics. For one variable (frequency, relative proportions) we have used mainly Chisquare test of independence. It is used to test the categorical variable weather there is a relationship between 
these variables or not. In analyzing this relationship, we started from Pivot Tables and Pivot coefficients. For the analysis of the difference between observed (empirical) and expected (theoretical) frequency, we used the Pearson chi-square test. Besides this, we also used a similar M-V chi-square test, which is based on the theory of maximum likelihood that is used in the case that there is a real dependence between variables. If the value corresponds to the chi-square probability $p>0.05$, this means that the relationship between variables is not statistically significant, and vice versa, if $p \leq 0.05$, it is possible strong relationship between two variables tested using one of the contingency factors. The Phi coefficient determines the degree of correlation between two categorical variables for $2 \times 2$ tables. Its value ranges from -1 to 1 (total dependence) or 0 (variables are not correlated with each other). The hypothesis was verified at 5\% significance level $(\alpha=0.05)$.

In the research we have set these three research hypotheses:

H 1: Companies with a higher about average value of ROE use specialized MIS type CRM (Customer Relationship Management).

H 2: We assume that if enterprises only use the ERP information system, they achieve signifi-cantly a poorer performance compared to enterprises using a specialized managerial information system support type CRM.

H 3: Enterprises with a higher size of ROE use specialized knowledge-based IS type Business Intelligence.

\section{Research findings}

\subsection{The use of ERP information systems in Slovakia and EU countries}

The Table 3 and Figure 4 show the level of use of ERP information systems in small, medium and large enterprises in Slovakia and other EU countries in years 2012 - 2015.

Table 3. The level of ERP implementation in Slovakia and EU 28 countries (in \%)

\begin{tabular}{|c|c|c|c|c|}
\hline $\begin{array}{c}\text { Year } \\
\text { Country }\end{array}$ & 2012 & 2013 & 2014 & 2015 \\
\hline \multicolumn{5}{|c|}{ Large enterprises (without financial sector) } \\
\hline European Union (28 countries) & 68 & 73 & 76 & 80 \\
\hline Slovakia & 62 & 64 & 69 & 71 \\
\hline \multicolumn{5}{|c|}{ Medium enterprises (without financial sector) } \\
\hline European Union (28 countries) & 44 & 49 & 54 & 60 \\
\hline Slovakia & 34 & 44 & 46 & 48 \\
\hline \multicolumn{5}{|c|}{ All enterprises (10 persons employed or more) - without financial sector } \\
\hline European Union (28 countries) & 23 & 27 & 32 & 36 \\
\hline Slovakia & 20 & 31 & 29 & 31 \\
\hline
\end{tabular}

Source: Eurostat, 2016 


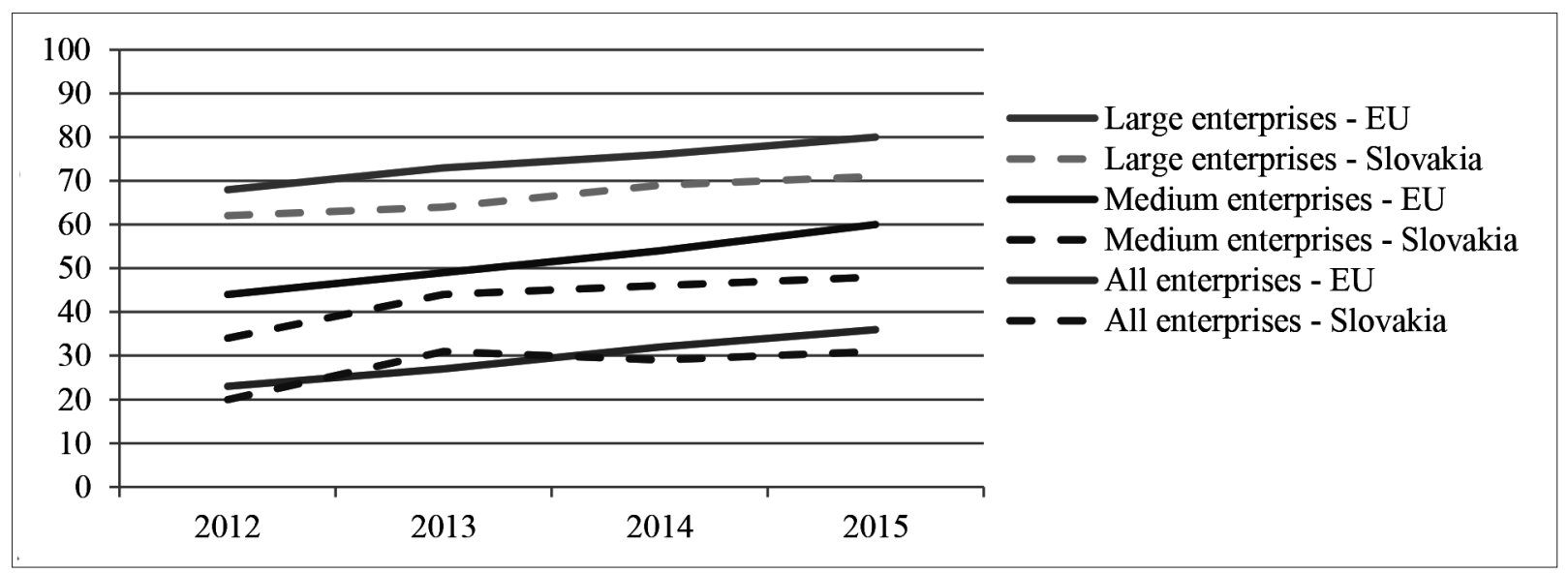

Figure 4. The use of ERP in enterprises in EU countries and Slovakia (in \%)

Source: own

From Table 3 and Figure 4 we can conclude, that the rate of use of ERP systems in EU enterprises and also in Slovakia in the last period of years 2012-2015 continues to grow up. Also, it can be observed the fact that the use of ERP is higher in medium and especially in large enterprises. Slovak medium and large enterprises achieve a lower level of use than other EU enterprises. In the category "All enterprises" (10 employed persons or more) is the rate of use the lowest and the difference between EU and Slovakia enterprises is moderate. In recent years 2013 - 2015 ERP information system has been implemented approximately only in 30\% of Slovak enterprises. In our own research sample ( $\mathrm{N}=164$ enterprises), ERP IS was used by 56 enterprises, so the rate of use accounted for $34 \%$. This rate is slightly higher, because in our survey sample was also micro sized enterprises (to 10 employees), that accounted for $29.9 \%$ share of the sample. These enterprises use ERP only quite rarely, so our own research sample was absolutely correct even in comparison to European Eurostat statistics.

\subsection{The impact of ERP and MIS on business performance of industrial firms in case of Slovakia}

In presenting results we focused on statistically significant dependence (p-value $<0.05$, which is the alpha level associated with a $95 \%$ confidence level). On the base of our research we can conclude, that the basic information system ERP affects the business performance of the firm. However, the residue levels (Table 4) lead us to the conclusion that companies using only a basic ERP IS most often reach a negative or very low ROE of levels below $2 \%$.

Table 4. ERP Basic Information System x Performance - Frequency

\begin{tabular}{|c|c|c|c|c|}
\hline $\begin{array}{l}\text { The basic ERP } \\
\text { information system }\end{array}$ & $\begin{array}{c}\text { Group } 1 \\
\text { Poor performance } \\
(\mathrm{ROE}<0,0-2 \%)\end{array}$ & $\begin{array}{c}\text { Group } 2 \\
\text { Medium performance } \\
(\text { ROE } 2-4 \%, 4-7 \%)\end{array}$ & $\begin{array}{c}\text { Group } 3 \\
\text { High Performance } \\
(\text { ROE } 7-10 \% \text {, above } 10 \%)\end{array}$ & $\begin{array}{l}\text { Row } \\
\text { totals }\end{array}$ \\
\hline \multicolumn{5}{|c|}{ The observed frequency } \\
\hline We do not use ERP & 39 & 48 & 21 & 108 \\
\hline We use ERP & 33 & 13 & 10 & 56 \\
\hline Total & 72 & 61 & 31 & 164 \\
\hline \multicolumn{5}{|c|}{ Expected frequency } \\
\hline We do not use ERP & 47.41463 & 40.17073 & 20.41463 & 108.0000 \\
\hline We use ERP & 24.58537 & 20.82927 & 10.58537 & 56.0000 \\
\hline Total & 72.00000 & 61.00000 & 31.00000 & 164.0000 \\
\hline \multicolumn{5}{|c|}{ Observed minus the expected frequencies (residue) } \\
\hline We do not use ERP & -8.41463 & $\mathbf{7 . 8 2 9 2 7}$ & 0.585366 & 0.00 \\
\hline We use ERP & 8.41463 & -7.82927 & -0.585366 & 0.00 \\
\hline Total & 0.00000 & 0.00000 & 0.000000 & 0.00 \\
\hline
\end{tabular}


The application of the CRM information system was shown as statistically significant, but residue levels (Table 5) show that companies that apply the CRM information system typically achieve a negative or very low performance level of only up to $2 \%$.

Table 5. CRM Information System x performance - Frequency

\begin{tabular}{|c|c|c|c|c|}
\hline $\begin{array}{l}\text { CRM information } \\
\text { system }\end{array}$ & $\begin{array}{c}\text { Group } 1 \\
\text { Poor performance } \\
(\mathrm{ROE}<0,0-2 \%) \\
\end{array}$ & $\begin{array}{c}\text { Group } 2 \\
\text { Medium performance } \\
(\mathrm{ROE} 2-4 \%, 4-7 \%)\end{array}$ & $\begin{array}{c}\text { Group } 3 \\
\text { High performance } \\
\text { (ROE } 7-10 \% \text {, above } 10 \%)\end{array}$ & $\begin{array}{l}\text { Row } \\
\text { Totals }\end{array}$ \\
\hline \multicolumn{5}{|c|}{ The observed frequency } \\
\hline Firm does not use CRM & 62 & 57 & 31 & 150 \\
\hline Firm uses CRM & 10 & 4 & 0 & 14 \\
\hline Total & 72 & 61 & 31 & 164 \\
\hline \multicolumn{5}{|c|}{ Expected frequency } \\
\hline Firm does not use CRM & 65.85366 & 55.79268 & 28.35366 & 150.0000 \\
\hline Firm uses CRM & 6.14634 & 5.20732 & 2.64634 & 14.0000 \\
\hline Total & 72.00000 & 61.00000 & 31.00000 & 164.0000 \\
\hline \multicolumn{5}{|c|}{ Observed minus the expected frequencies (residue) } \\
\hline Firm does not use CRM & -3.85366 & 1.20732 & 2.64634 & 0.00 \\
\hline Firm uses CRM & 3.85366 & -1.20732 & -2.64634 & 0.00 \\
\hline Total & 0.00000 & 0.00000 & 0.00000 & 0.00 \\
\hline
\end{tabular}

Source: own

The implementation of a knowledge Business Intelligence information system shows a statistically significant dependence. Residue levels (Table 6) suggest that if companies do not have a BI system in place and do not consider implementing it, the companies tend to reach a lower performance. The enterprises that currently use a BI achieve a better performance, with ROE over $4 \%$.

Table 6. The application of BI x Performance - Frequency

\begin{tabular}{|c|c|c|c|}
\hline $\begin{array}{l}\text { The application of Business } \\
\text { Intelligence (BI) }\end{array}$ & $\begin{array}{c}\text { Group } 1 \\
\text { Poor performance } \\
(\mathrm{ROE}<0,0-2 \%, 2-4 \%) \\
\end{array}$ & $\begin{array}{c}\text { Group } 2 \\
\text { High performance } \\
\text { (ROE } 4-7 \%, 7-10 \% \text {, above } 10 \%)\end{array}$ & $\begin{array}{l}\text { Row } \\
\text { totals }\end{array}$ \\
\hline \multicolumn{4}{|c|}{ The observed frequency } \\
\hline We do not consider it & 82 & 35 & 117 \\
\hline We consider it long-term & 15 & 11 & 26 \\
\hline We consider it in the near future & 8 & 2 & 10 \\
\hline The firm already uses it & 2 & 9 & 11 \\
\hline Total & 107 & 57 & 164 \\
\hline \multicolumn{4}{|c|}{ Expected frequency } \\
\hline We do not consider it & 76.3354 & 40.66463 & 117.0000 \\
\hline We consider it long-term & 16.9634 & 9.03659 & 26.0000 \\
\hline We consider it in the near future & 6.5244 & 3.47561 & 10.0000 \\
\hline The firm already uses it & 7.1768 & 3.82317 & 11.0000 \\
\hline Total & 107.0000 & 57.00000 & 164.0000 \\
\hline \multicolumn{4}{|c|}{ Observed minus the expected frequencies (residue) } \\
\hline We do not consider it & 5.66463 & -5.66463 & 0.00 \\
\hline We consider it long-term & -1.96341 & 1.96341 & 0.00 \\
\hline We consider it in the near future & 1.47561 & -1.47561 & 0.00 \\
\hline The firm already uses it & -5.17683 & 5.17683 & 0.00 \\
\hline Total & 0.00000 & 0.00000 & 0.00 \\
\hline
\end{tabular}

Source: own 


\section{Discussion}

Based on the results presented in the previous chapter, the following conclusions are reached for the research hypotheses formulated:

H 1: $\mathrm{H} 0$ was rejected in favour of $\mathrm{H} 1$ for companies using specialized managerial information systems of the CRM type, which had statistically significant impact on the level of business performance of ROE. But our research results show that enterprises applying only the CRM information system typically achieve a negative or poor performance level a maximum up to $2 \%$ of ROE.

H 2: $\mathrm{HO}$ is rejected in favour of $H_{1}$ for companies using only basic ERP IS, as these were shown to influence the firm's performance. The firms which only use the basic ERP achieve a lower performance, with the levels of ROE being negative or very low a maximum up to $2 \%$.

H 3: H0 was confirmed. The use of the IS Business Intelligence type was found to have a positive impact on the performance of the firm. The analysis shows that there are two categories of companies - companies that use a BI system which achieve ROE of over $4 \%$, and businesses that do not even consider the implementation of an IS and whose economic performance is lower, as shown by ROE below 4\%.

The survey carried out on the sample of 164 enterprises operating in Slovakia investigated the implementation, respectively using of $\mathrm{BI}$ in relation to company ROE value. The results show that ERP information system has been implemented approximately in $34 \%$ of Slovak enterprises, but only $7 \%$ of enterprises have implemented and use a system of BI, whereby these companies belong to the group with the ROE more than $4 \%$. The research results showed that in the case that companies do not have the BI information system as a complex system and not take into account its implementation they tend to have a lower level of performance. On the other hand, businesses that currently use BI system they achieve a better performance with a ROE of more than $4 \%$. It follows that the BI system has a major impact on business performance.

The most important findings of our research present also the following Figure 5.

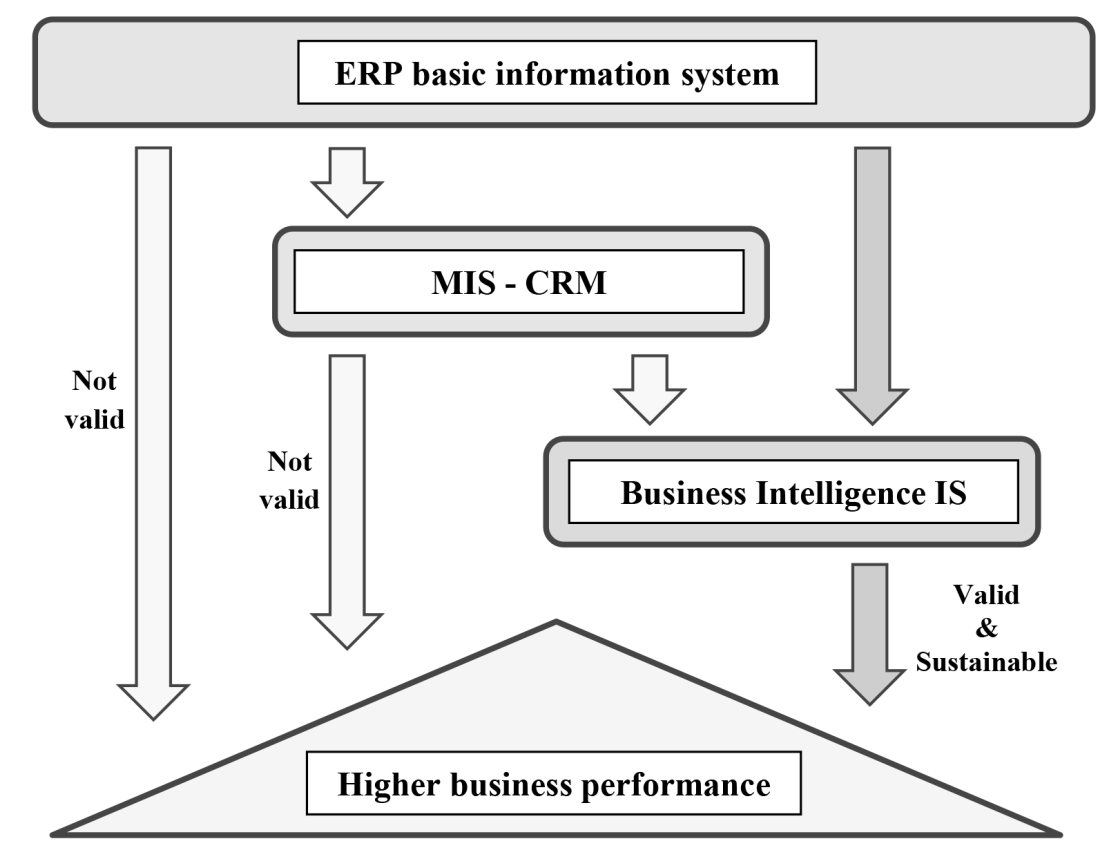

Figure 5. From ERP to Business Intelligence - The most important research findings 


\section{Conclusion}

Many organizations continue to increase their investment in implementing various types of information systems, such as Enterprise Resource Planning (ERP) and Customer Relationship Management (CRM). The rate of use of ERP systems in EU enterprises and also in Slovakia in the last period of years 2012 - 2015 continues to grow up. The enterprises in the EU countries were invested a lot of financial resources into the implementation of ERP information systems. Moreover, the empirical findings suggest that the potential for investment in ERP to generate substantial productivity gains may actually be greater for enterprises in developing countries than those in developed economies. Also, it can be observed the fact that the use of ERP is higher in medium and especially in large enterprises. Slovak medium and large enterprises achieve a lower level of use than other EU enterprises. In the category "All enterprises" (10 employed persons or more) is the rate of use the lowest and the difference between EU and Slovakia enterprises is moderate. The our research results show that ERP information system has been implemented approximately in 34\% of Slovak enterprises, but only $7 \%$ of Slovak enterprises have implemented and use a knowledge information system of BI. The firms which only use the basic ERP are typically underperform. This our finding is contradict to other international studies that have found positive abnormal stock returns for firms using ERP also found evidence of improved financial performance immediately after ERP implementation (Stratman, 2007; Hitt, Wu \& Zhou 2002; McAfee, 2002; Cotteleer, 2006). The presented empirical findings can partially be related to research on the effectiveness of ERP implementation process that shows that the ERP absorption level is achieved with significantly less efficiency and effectiveness in transition economies (Bernroider et al., 2011; Rajnoha et al., 2014), and with difficulties resulting from organizational conditions, including problems with training and consultants. This finding shows that the implementation of the basic ERP within an enterprise should be further supported by the implementation and development of an MIS. From our research is evident that the key tool in increasing the overall business performance of the enterprise in the selected Slovak industries seems to be employing a knowledge-based Business Intelligence information system. The results bring the findings that a quality BI IS based on information and knowledge with a high added value has a positive long-term and sustainable effect on the business performance of the company. We believe that our study presented in this paper contributes to explore a new dimension to the existing view on business information systems in industrial companies. Therefore, we continue in our research to bring more relevant results.

\section{Acknowledgments}

This paper is the partial result of the GAAA - Grantová agentura Akademické aliance grant project Nr. GAAA 3_2/2016 - Strategic business performance measurement and management and its comparison in Czech and Slovak companies.

The contribution is the partial result of VEGA grant Project No. 1/0255/2016 - The research on the possibility of optimization of process-oriented models of the financial administration management with a focus on transfer pricing and tax harmonization in the terms of EU.

\section{References}

Akhter, F. (2017). Unlocking digital entrepreneurship through technical business process. Entrepreneurship and Sustainability Issues, 5(1), 36-42. http://doi.org/10.9770/jesi.2017.5.1(3)

Aleksejeva, L. (2016). Country's competitiveness and sustainability: higher education impact. Journal of Security and Sustainability Issues, 5(3), 355-363. http://doi.org/10.9770/jssi.2015.5.3(4)

Basl, J., \& Blažíček, R. (2008). Podnikové informačni systémy. (2 ${ }^{\text {nd }}$ ed.). Praha: Grada, (Chapter 4).

Belás, J., \& Gabčová, L. (2016). The Relationship among Customer Satisfaction, Loyalty and Financial Performance of Commercial Banks. E + M Ekonomie a Management, 19(1), 132-147. http://doi.org/10.15240/tul/001/2016-1-010

Belás, J., Korauš, M., Kombo, F., \& Korauš, A. (2016). Electronic banking security and customer satisfaction and in commercial banks. Journal of Security and Sustainability Issues, 5(3), 411-422. http://dx.doi.org/10.9770/jssi.2016.5.3(9) 
Belás, J., Vojtovič, S., \& Ključnikov, A. (2016). Microenterprises and Significant Risk Factors in Loan Process. Economics and Sociology, 9(1), 43-59. http://doi.org/10.14254/2071-789X.2016/9-1/3

Bernroider, E. W., Sudzina, F., \& Pucihar, A. (2011). Contrasting ERP Absorption between Transition and Developed Economies from Central and Eastern Europe (CEE). Information Systems Management, 28(3), 240-257.

Chen, H., Chiang, R., \& Storey, V. (2012). Business Intelligence and Analytics: from Big Data to Big Impact. MIS Quarterly, Special Issue: Business Intelligence Research, 36(4), 1165-1188. Retrieved from http://www.misq.org/skin/frontend/default/misq/pdf/V36I4/ SI_ChenIntroduction.pdf

Chernov, V., Dorokhova, L. \& Dorokhov, O. (2016), Fuzzy Approach to Estimates Entropy and Risks for Innovative Projects and Programs. Montenegrin Journal of Economics, 12(3), 55-68

Chromjaková, F., \& Rajnoha, R. (2009). Economy of Innovation as a Part of the Increase of the Company Performance. Journal of Competitiveness, 1(1), 66-74. http://www.cjournal.cz/files/7.pdf

Čirjevskis, A. (2016). Sustainability in information and communication technologies’ industry: innovative ambidexterity and dynamic capabilities perspectives. Journal of Security and Sustainability Issues, 6(2), 211-226. http://dx.doi.org/10.9770/jssi.2016.6.2(2)

Cotteleer, M. J. (2006). An empirical study of operational performance parity following enterprise system deployment. Production and Operations Management, 15(1), 74-87.

Hakim, A., \& Hakim, H. (2010). A practical model on controlling the ERP implementation risks. Information systems. 35(2), $204-214$. http://dx.doi.org/10.1016/j.is.2009.06.002

Hitt, L.M., Wu, D.J., \& Zhou, X. (2002). Investment in Enterprise Resource Planning: Business Impact and Productivity Measures. Journal of Management Information Systems, 19(1), 71-98.

Hou, Ch. K. (2012). Examining the effect of user satisfaction on system usage and individual performance with business intelligence systems: An empirical study of Taiwan's electronics industry. International Journal of Information Management, 32(6), 560-573. http://doi.org/10.1016/j.ijinfomgt.2012.03.001

Ignatavičius, R.; Tvaronavičienè, M.; Piccinetti, L. (2015). Sustainable development through technology transfer networks: case of Lithuania. Journal of Security and Sustainability Issues 4(3): 261-267. DOI: http://dx.doi.org/10.9770/jssi.2015.4.3(6)

Illmeyer, M.; Grosch, D.; Kittler, M.; Pamela Priess. P. (2017). The impact of financial management on innovation. Entrepreneurship and Sustainability Issues 5(1), 58-71. http://doi.org/10.9770/jesi.2017.5.1(5)

Juřičková, E., \& Novák, P. (2015). Trends in Innovation Performance of leading Economies in the European Union. Economics Management Innovation, 7(2), 3-18. Available at: http://www.emijournal.cz/

Korauš, A., Dobrovič, J., Ključnikov, A., \& Gombár, M. (2016). Consumer approach to bank payment card security and fraud. Journal of Security and Sustainability Issues, 6(1), 85-102. http://dx.doi.org/10.9770/jssi.2016.6.1(6)

Kriviņš, A. (2015). Towards security and safety: police efficiency across European countries. Journal of Security and Sustainability Issues 5(1). 35-44. http://dx.doi.org/10.9770/jssi.2015.5.1(3)

Li, S., Shue, L., \& Lee, S. (2008). Business intelligence approach to supporting strategy - making of ISP service management. Expert Systems with Applications, 35(3), 739-754. http://doi.org/10.1016/j.eswa.2007.07.049

Lönnqvist, A., \& Pirttimäki, V. (2006). The Measurement of Business Intelligence. INFORMATION SYSTEMS MANAGEMENT, 23(1), 32-40. http://dx.doi.org/10.1201/1078.10580530/45769.23.1.20061201/91770.4

Mabert, V. A., Ashok, S., \& Venkataramanan, M. A. (2003). Enterprise resource planning: Managing the implementation process. European Journal of Operational Research, 146(2), 302-314.

Manley, K. (2003). Frameworks for Understanding Interactive Innovation Processes. International Journal of Entrepreneurship and Innovation, 4(1), 25-36.

McAfee, A. (2002). The impact of enterprise information technology adoption on operational performance: An empirical investigation. Production and Operations Management, 11(1), 33-53.

O’Reilly, C., \& Tushman, M. (2013). Organizational ambidexterity: Past, Present, and Future. The Academy of Management Perspectives, 27(4), 324-338. http://doi.org/10.5465/amp.2013.0025 
Oganisjana, K.; Svirina, A.; Surikova, S.; Grīnberga-Zālīte, G.; Kozlovskis. K. (2017). Engaging universities in social innovation research for understanding sustainability issues. Entrepreneurship and Sustainability Issues, 5(1), 9-22. http://doi.org/10.9770/jesi.2017.5.1(1)

Prause, G. (2015). Sustainable business models and structures for industry 4.0. Journal of Security and Sustainability Issues, 5(2), 159169. http://dx.doi.org/10.9770/jssi.2015.5.2(3)

Rajnoha, R., Kádárová, J., Sujová, A., \& Kádár, G. (2014). Business information systems: research study and methodological proposals for ERP implementation process improvement. Procedia - Social and Behavioral Sciences Journal, 109, 165-170. http://doi. org/10.1016/j.sbspro.2013.12.438

Rajnoha, R., Novák, P \& Merková, M. (2016). Relationships Between Investment Effectiveness Controlling and Business Performance. Montenegrin Journal of Economics, 12(2), 29-44.

Rajnoha, R., Štefko, R., Merková, M., \& Dobrovič, J. (2016). Business Intelligence as a Key Information and Knowledge Tool for Strategic Business Performance. E + M Ekonomie a Management, 19(1), 183-203. http://doi.org/10.1524.0/tul/001/2016-1-013

Ram, J., \& Corkindale, D. (2014). "How “critical” are the critical success factors (CSFs)?: Examining the role of CSFs for ERP. Business Process Management Journal, 20(1), 151-174. http://dx.doi.org/10.1108/BPMJ-11-2012-0127

Relich, M. (2013). Project parameter estimation on the basis of an ERP database. Foundations of Management, 5(2), 49-58. http://doi. org/10.2478/fman-2014-0012

Rosha, A., \& Lace, N. (2015). Sustainable development and behavioural patterns: to innovations through coaching. Journal of Security and Sustainability Issues, 5(2), 171-180. http://dx.doi.org/10.9770/jssi.2015.5.2(4)

Štefko, R., Fedorko, R., \& Bačík, R. (2015). The Role of E-marketing Tools in Constructing the Image of a Higher Education Institution. Procedia-Social and Behavioral Sciences, 175, 431-438. http://doi.org/10.1016/j.sbspro.2015.01.1220

Štefko, R., Királ'ová, A., \& Mudrík, M. (2015). Strategic Marketing Communication in Pilgrimage Tourism. Procedia-Social and Behavioral Sciences, 175, 423-430. http://doi.org/10.1016/j.sbspro.2015.01.1219

Stratman, J. (2007). Realizing Benefits from Enterprise Resource Planning: Does Strategic Focus Matter? Production and Operations Management, 16(2), 203-216. http://doi.org/10.1111/j.1937-5956.2007.tb00176.x

Tetsman, I.; Bazienè, K.; Viselga, G. (2017). Technologies for sustainable circular business: using crushing device for used tires, Entrepreneurship and Sustainability Issues, 4(4), 432-440. https://doi.org/10.9770/jesi.2017.4.4(3)

Tuček, D., Tučková, Z., \& Zámečník, R. (2009). Business Process Management with Software Support. In K.S. Soliman (Eds.), Knowledge management and innovation in advancing economies-analyses \& solutions, 1-3, 1060-1073, Norristown: International Business Information Management Association - IBIMA.

Tutunea, M., \& Rus, R. (2012). Business Intelligence solutions for SME's. Procedia Economics and Finance, 3, 865-870. http://doi. org/10.1016/S2212-5671(12)00242-0

Tvaronavičienė, A., Žemaitaitienè, G., \& Bilevičienè, T. (2016). Ecosystem for sustainable entrepreneurship: towards smart public procurement review procedures. Entrepreneurship and Sustainability Issues, 4(1), 39-52. http://dx.doi.org/10.9770/jesi.2016.4.1(4)

Tvaronavičienè, M. (2017). Clusters, innovations and energy efficiency: if relantionship could be traced, Marketing and Management of Innovations, 2: 382 - 391. http://dx.doi.org/10.21272/mmi.2017.2-35

Tvaronavičienė, M.; Černevičiūtè, J. (2015). Technology transfer phenomenon and its impact on sustainable development. Journal of Security and Sustainability Issues 5(1): 87-97. DOI: http://dx.doi.org/10.9770/jssi.2015.5.1(7)

Umble, E. J., Haft, R. R., \& Umble, M. M. (2003). Enterprise resource planning: Implementation procedures and critical success factors. European Journal of Operational Research, 146(2), 241-257.

Wu, J. H., \& Wang, Y. M. (2007). Measuring ERP success: The key-users' viewpoint of the ERP to produce a viable IS in the organization. Computers in Human Behavior, 23(3), 1582-1596. http://dx.doi.org/10.1016/j.chb.2005.07.005

Wu, L., Ong, C., \& Hsu, Y. (2008). Active ERP implementation management: A Real Options perspective. The Journal of Systems and Software, 81(6), 1039-1050. http://dx.doi.org/10.1016/j.jss.2007.10.004 